\title{
Efficacy of Heat Treatment for Disinfestation of Concrete Grain Silos
}

\author{
G. P. OPIT,${ }^{1,2}$ F. H. ARTHUR,${ }^{3}$ E. L. BONJOUR, ${ }^{1}$ C. L. JONES,${ }^{4}$ AND T. W. PHILLIPS ${ }^{5}$
}

J. Econ. Entomol. 104(4): 1415-1422 (2011); DOI: 10.1603/EC11104

\begin{abstract}
Field experiments were conducted in 2007 and 2008 to evaluate heat treatment for disinfestations of empty concrete elevator silos. A Mobile Heat Treatment Unit was used to introduce heat into silos to attain target conditions of $50^{\circ} \mathrm{C}$ for at least $6 \mathrm{~h}$. Ventilated plastic containers with a capacity of $100 \mathrm{~g}$ of wheat, Triticum aestivum L., held Rhyzopertha dominica (F.) (Coleoptera: Bostrichidae) and Tribolium castaneum (Herbst) (Coleoptera: Tenebrionidae). Polyvinyl chloride containers with a capacity of $300 \mathrm{~g}$ of wheat held adults of Liposcelis corrodens (Heymons) (Psocoptera: Liposcelididae) and Liposcelis decolor (Pearman), which were contained in 35-mm Petri dishes within the grain. Containers were fastened to a rope suspended from the top of the silo at depths of $0 \mathrm{~m}$ (just under the top manhole), $10 \mathrm{~m}, 20 \mathrm{~m}$, and $30 \mathrm{~m}$ (silo floor). When the highest temperature achieved was $\approx 50^{\circ} \mathrm{C}$ for $6 \mathrm{~h}$, parental mortality of $R$. dominica and T. castaneum, and both psocid species was $98-100 \%$. Progeny production of $R$. dominica occurred when there was parental survival, but in general $R$. dominica seemed less impacted by the heat treatment than T. castaneum. There was $100 \%$ mortality of $L$. corrodens at all depths in the heat treatments but only $92.5 \%$ mortality for $L$. decolor, with most survivors located in the bioassay containers at the top of the silo. Results show wheat kernels may have an insulating effect and heat treatment might be more effective when used in conjunction with sanitation and cleaning procedures.
\end{abstract}

KEY WORDS Rhyzopertha dominica, Tribolium castaneum, Liposcelis corrodens, Liposcelis decolor, heat treatment

Two major pests of stored grain are Rhyzopertha dominica (F.) (Coleoptera: Bostrichidae) and Tribolium castaneum (Herbst) (Coleoptera: Tenebrionidae). The former is a major internal-infesting pest of whole cereal, whereas the latter is an important externalinfesting pest of cereals and cereal products and is a major pest of mills (Rees 2004). These pests are commonly controlled using insecticides, but development of insecticide resistance (Zettler and Cuperus 1990) and government regulation of insecticides, consumer demand for insecticide residue-free products, and broader commercial needs call for the development of chemical-free management approaches for these pests (Phillips and Throne 2010). Psocids (Psocoptera) contain species in the genus Liposcelis that are major pests of stored products (Rees 2004, Phillips and Throne 2010). Before 1990, psocids were not consid-

\footnotetext{
Mention of trade names or commercial products in this publication is solely for the purpose of providing specific information and does not imply recommendation or endorsement by the U.S. Department of Agriculture or by Oklahoma State University.

${ }^{1}$ Department of Entomology and Plant Pathology, Oklahoma State University, 127 Noble Research Center, Stillwater, OK 74078-3033.

2 Corresponding author, e-mail: george.opit@okstate.edu.

${ }^{3}$ Center for Grain and Animal Health Research, USDA-ARS, 1515 College Ave., Manhattan, KS 66502-2736.

${ }^{4}$ Department of Biosystems and Agricultural Engineering, Oklahoma State University, 216 Agriculture Hall, Stillwater, OK 74078.

${ }^{5}$ Department of Entomology, Kansas State University, 123 West Waters Hall, Manhattan, KS 55506-4004.
}

ered serious pests of stored products; however, in Australia, they have become the most frequently encountered storage pest in some areas (Rees 2003). The increased concerns regarding psocids can be attributed to their varied response to management tactics that have been developed for coleopteran pests, e.g., some psocid species are resistant to residual insecticides and the fumigant phosphine (Nayak et al. 1998, 2002a,b, 2003; Nayak 2006). In addition, markets increasingly view psocids as contaminants (Kučerová 2002, Nayak 2006).

Stored-product insects that infest newly harvested stored grain can rapidly increase in numbers given the right environmental factors (Hagstrum 1989). A common insecticidal treatment worldwide for management of stored grain is fumigation with phosphine (Taylor 1989, Chaudhry 2000). In addition, phosphine is recommended for the disinfestations of empty grain storage structures. Phosphine is cheap, easy to apply, leaves no residues, and can be used in a wide range of storage types and commodities (Nayak and Collins 2008). However, phosphine resistance in stored-product insect pests is already a major problem in many countries, with very high levels of resistance found in some parts of Asia and Africa (Mills 1983, Taylor and Halliday 1986, Taylor 1989, Zettler 1997, Sayaboc et al. 1998) and in the United States as well (Zettler and Cuperus 1990). Therefore, alternatives to phosphine 
fumigation could reduce selection pressure and reduce the frequency of resistance alleles.

Heat treatment is an ecologically based technique that can be used as an alternative to pesticides for the control of stored-product insect pests in food processing facilities and empty grain storages. Since the early 1900 s, heat treatments have been recognized as an effective strategy for insect control in flour mills (Dean 1911, 1913). More recently, heat has been used to successfully control insect pests in grain processing facilities (Mahroof et al. 2003a, Roesli et al. 2003). During heat treatment, the temperature of the target structure is raised to $50-60^{\circ} \mathrm{C}$ and maintained at these elevated temperatures for 24-36 h to kill stored-product insects (Mahroof et al. 2003a,b).

Tilley et al. (2007) conducted studies that demonstrated the potential for using heat to disinfest empty steel grain storage bins. The bins used in these studies were of 109 MT-storage capacity (4,000 bushels), which are relatively small bins for storing grain onfarm. Another study by Beckett and Qaisrani (2003) investigated the use of heat to disinfest empty 50-MT metal silos. They suggested that heat disinfestation is effective and economical when high inlet temperatures are used to produce rapid heating to a temperature where complete insect mortality is guaranteed. In the United States, concrete silos are widely used for grain storage in most country and terminal elevators (Bailey 1992). There is no published study in the scientific literature evaluating heat treatment for managing insect pests in empty concrete silos. Several recent studies have documented extensive insect infestations in residual grain found in the bottoms of elevator silos and in selected areas within the elevator environment (Reed et al. 2003, Arthur et al. 2006). Therefore, the objective of this study was to evaluate the efficacy of heat treatments for disinfestation of concrete silos of $R$. dominica, T. castaneum, and two psocid species, Liposcelis corrodens (Heymons) (Psocoptera: Liposcelididae) and Liposcelis decolor (Pearman).

\section{Materials and Methods}

Silos and Heat Application. In total, six empty concrete silos located in Marshall, OK, were used for the experiment in 2007 and 2008. In 2007, heat treatment was conducted from 15 to 17 April and in 2008 from 29 April to 1 May. In both years, the silos were paired for testing so that a heated silo would not share a wall with a control silo on the day of testing. The silos were $\approx 32$ $\mathrm{m}$ in height, with a diameter of $6 \mathrm{~m}$. Each silo contained a manhole opening with a cover at the top and an access hole close to the bottom of the silo. Silos used for controls had no introduced heat.

A Mobile Heat Treatment Unit (model MHT-1500, TempAir, Burnsville, MN) with a heat output potential of $440 \mathrm{~kW}$ was used to generate heat, which was introduced into the access hole close to the bottom of each test silo via a flexible duct with holes to distribute air. The flexible duct was positioned so that heat would be distributed evenly throughout the silo. When the temperature in the heat-treated silo reached $50^{\circ} \mathrm{C}$ timing was initiated and heating was continued for the next $6 \mathrm{~h}$ after which the heater was turned off.

Beetles. $R$. dominica were reared on a mixture of 95\% whole-wheat kernels and 5\% Brewer's yeast (wt: wt) at $28^{\circ} \mathrm{C}$ and $65 \% \mathrm{RH}$, and T. castaneum were reared on a mixture of $95 \%$ all-purpose wheat flour and $5 \%$ Brewer's yeast at $28^{\circ} \mathrm{C}$ and $65 \% \mathrm{RH}$. Voucher specimens of $R$. dominica and T. castaneum that were used in this study are deposited at K. C. Emerson Entomology Museum at Oklahoma State University under lot numbers 104 and 105.

Experimental arenas. Arenas for the beetle mortality studies were plastic containers $(5.7 \mathrm{~cm}$ in height and $6.4 \mathrm{~cm}$ in diameter, with a $3.8-\mathrm{cm}$ hole cut in the screw-on lids. A screen (U.S. \#40 mesh) was mounted over the holes for ventilation. Arenas for $R$. dominica comprised $80 \mathrm{~g}$ of infested wheat, Triticum aestivum $\mathrm{L}$., plus $2.5 \mathrm{~g}$ of dust from the culture jars, which was presumed to contain eggs and neonates (immatures), $15 \mathrm{~g}$ of uninfested wheat, $1.5 \mathrm{~g}$ all-purpose wheat flour, and 50 adult beetles. For T. castaneum, arenas comprised $85 \mathrm{~g}$ of newly ground wheat, $1.5 \mathrm{~g}$ of flour infested with mixed age larvae and eggs from laboratory cultures, and 50 adult beetles. The arenas were fastened with plastic ties to a rope suspended from the top of the silo at depths of $0 \mathrm{~m}$ (just under the top manhole), $10 \mathrm{~m}, 20 \mathrm{~m}$, and $30 \mathrm{~m}$ (silo floor). A HOBO temperature recording device (Onset Computer Corporation, Bourne, MA) also was attached to the rope near the insect containers to record temperature surrounding the containers. Grain temperature in the middle of the arenas was not measured during the 2007 experiment, but because of higher than expected insect survival, measurements were made during the 2008 experiment to determine whether the temperature in the arenas was congruent to that outside.

Ropes with the arenas fastened to them were placed in the silos to be tested on the afternoon before the testing began; testing began the next morning. After heating the heat-treated silo for $6 \mathrm{~h}$ at $50^{\circ} \mathrm{C}$, the ropes with arenas were removed immediately and the arenas were taken to the laboratory for processing. Adult beetles were removed from the grain using sieves (U.S. Standard \#10 sieve with 2-mm openings) and counted as live or dead. Moribund and dead adults were placed in a $9-\mathrm{cm}$ petri dish containing a piece of filter paper moistened with $0.5 \mathrm{ml}$ of water; these insects were then reevaluated after $24 \mathrm{~h}$ for recovery. The grain, from which all adult beetles had been removed, was returned to the arenas and placed in a growth chamber held at $28^{\circ} \mathrm{C}$ and $70 \% \mathrm{RH}$. The grain was sifted twice, after 2 and $4 \mathrm{wk}$, to remove any progeny present. These progeny (T. castaneum and $R$. dominica) were counted and summed over the 4 -wk period. Three replications were completed, each on consecutive days in the spring and daytime temperatures during this period were consistent. A replication consisted of one heat treated silo and one silo under ambient conditions with no external heat source. The three temporal replications arise from the fact that only one replication was conducted on any given day 
Table 1. Temperature (Celsius) ranges and means $\pm \mathrm{SE}$ in untreated (control) silos $(n=3)$

\begin{tabular}{lccccc}
\hline \hline \multirow{2}{*}{ Depth $(\mathrm{m})$} & \multicolumn{2}{c}{2007} & & \multicolumn{2}{c}{2008} \\
\cline { 2 - 3 } \cline { 5 - 6 } & Range & Mean & & Range & Mean \\
\hline 0 (top) & $23.2-31.1$ & $25.2 \pm 1.5 \mathrm{a}$ & & $14.9-32.8$ & $23.2 \pm 2.2 \mathrm{a}$ \\
10 & $21.3-29.1$ & $23.0 \pm 0.9 \mathrm{~b}$ & & $13.3-27.9$ & $20.4 \pm 2.7 \mathrm{~b}$ \\
20 & $20.2-31.5$ & $22.2 \pm 1.2 \mathrm{~b}$ & & $12.9-25.2$ & $19.5 \pm 3.4 \mathrm{~b}$ \\
30 (bottom) & $15.6-22.5$ & $19.4 \pm 1.0 \mathrm{c}$ & & $12.2-24.8$ & $17.3 \pm 3.3 \mathrm{c}$ \\
\hline
\end{tabular}

Means within a column followed by different letters are significantly different. ANOVA results for 2007 and 2008 temperatures were $F=16.2 ; \mathrm{df}=3,6 ; P<0.01$ and $F=42.6$ df $=3,6 ; P<0.01$, respectively.

and the study was conducted over three consecutive days.

Psocids. Psocids were used in only the 2008 heat treatment. L. decolor and L. corrodens cultures used in the study were started with insects collected during summer 2006. Individuals for starting the L. decolor culture were collected from wheat stored in steel grain storage bins at the Center for Grain and Animal Health Research in Manhattan, KS, and those for L. corrodens culture from a grain elevator at the same location. Voucher specimens of L. corrodens and L. decolor used have been deposited in the Kansas State University Museum of Entomological and Prairie Arthropod Research under lot numbers 204 and 205. Psocids were reared on a mixture of $93 \%$ cracked hard red winter wheat, $5 \%$ wheat germ, and $2 \%$ Rice Krispies (wt:wt) in 0.473-liter glass canning jars covered with miteproof lids, and cultures were maintained at $30^{\circ} \mathrm{C}$ and $75 \% \mathrm{RH}$.

Experimental arenas. Arenas for psocids were constructed of a $10-\mathrm{cm}$ length of 7.6-cm-diameter plastic (polyvinyl chloride) pipe with two end caps. Each end cap had a 3.8-cm hole cut in the center with a screen (U.S. \#40 mesh) mounted over the hole for ventilation. Each arena was filled with $300 \mathrm{~g}$ of uninfested wheat. Two 35-mm petri dishes, each containing 20 adult female L. decolor or L. corrodens, $0.5 \mathrm{~g}$ of colored psocid diet (Opit and Throne 2008), and 10 particles of cracked hard red winter wheat were placed in each arena. Psocid arenas were suspended at the same depths and adjacent to the beetle arenas as already described. The numbers of live and dead psocids in each petri dish were determined immediately after the experiment was terminated. The experiment had three temporal replications over three consecutive days; each time a different pair of silos was used.
Data Analysis. The design for data analysis was a split plot design with temporal replications as blocks, heat or no heat as main effects or treatments, and depths from which insects were suspended as the subplot treatments. Data were percentages of dead insects and number of progeny, which were analyzed by species. The PROC UNIVARIATE statement with the PLOTS option was first used to test the distribution of the data before PROC GLM was used to perform analysis of variance (ANOVA) (SAS version 9.2, SAS Institute, Cary, NC) to determine the effect of heat, depth, and their interaction on insect mortality and progeny production. Percentage of mortality data were transformed using the arcsine square-root transformation to stabilize variances, but untransformed percentages and standard errors are reported to simplify interpretation. Despite the fact that depth had no statistically significant effect on the mortality of $L$. corrodens (at $\alpha=0.05$ ), we were concerned that the mortalities of psocids in the control treatment may be different. Therefore, we used the least significant difference (LSD) test for planned comparisons notwithstanding the nonsignificant $F$ value (Steel and Torrie 1960). Similarly, we were concerned that mortality of L. decolor at the top of the heated silos was considerably lower than at 10,20, and $30 \mathrm{~m}$ below the top. Therefore, we used the LSD test for planned comparisons notwithstanding the nonsignificant $F$ value (Steel and Torrie 1960).

\section{Results}

Silo Temperatures in 2007. In the control (unheated) silos, mean ambient temperatures decreased with depth from $25.2^{\circ} \mathrm{C}$ at the top of the bins to $19.4^{\circ} \mathrm{C}$ at the bottom ( $30 \mathrm{~m}$ below the top) and had a range of $15.6-31.5^{\circ} \mathrm{C}$ (Table 1 ). The reverse was observed in heated silos where mean temperatures increased with depth from the top $\left(43.6^{\circ} \mathrm{C}\right)$ to the bottom $\left(50.6^{\circ} \mathrm{C}\right)$ (Table 2 ), with a range of $17.5-53.5^{\circ} \mathrm{C}$. In the heated silos, a target ambient temperature of $50^{\circ} \mathrm{C}$ was more rapidly attained with increasing depth from the top to the bottom (4.7-2.4 h) (Table 3 ).

Silo and Container Temperatures in 2008. In the control silos, mean ambient temperatures decreased with depth from $23.2^{\circ} \mathrm{C}$ at the top of the silos to $17.3^{\circ} \mathrm{C}$ at the bottom (Table 1 ) with a range of $12.2-32.8^{\circ} \mathrm{C}$. In the heated silos, mean temperatures increased with depth from the top $\left(46.9^{\circ} \mathrm{C}\right)$ to $20 \mathrm{~m}\left(51.3^{\circ} \mathrm{C}\right)$ and then

Table 2. Temperatures (Celsius) (means \pm SE) in the heated silos $(n=3)$

\begin{tabular}{|c|c|c|c|c|c|}
\hline \multirow{2}{*}{ Depth $(\mathrm{m})$} & \multirow{2}{*}{$\frac{2007}{\text { Ambient }}$} & \multicolumn{4}{|c|}{2008} \\
\hline & & Ambient & T. castaneum containers & R. dominica containers & Psocid containers \\
\hline 0 (top) & $43.6 \pm 1.5 \mathrm{a}$ & $46.9 \pm 4.0 \mathrm{a}$ & $42.2 \pm 6.1 b$ & $42.7 \pm 7.0 \mathrm{~b}$ & $40.6 \pm 7.8 b$ \\
\hline 10 & $45.3 \pm 0.3 \mathrm{a}$ & $49.8 \pm 5.8 \mathrm{a}$ & $45.9 \pm 9.4 b$ & $46.2 \pm 9.5 b$ & \\
\hline 20 & $48.0 \pm 1.1 \mathrm{a}$ & $51.3 \pm 5.7 \mathrm{a}$ & $51.2 \pm 10.5 \mathrm{a}$ & $51.7 \pm 11.1 \mathrm{a}$ & $49.1 \pm 11.6 \mathrm{a}$ \\
\hline 30 (bottom) & $50.6 \pm 9.5 \mathrm{a}$ & $49.9 \pm 8.1 \mathrm{a}$ & $51.2 \pm 10.5 \mathrm{a}$ & $51.7 \pm 11.2 \mathrm{a}$ & $49.1 \pm 11.6 \mathrm{a}$ \\
\hline
\end{tabular}

Means within a column followed by different letters are significantly different. ANOVA results for 2007 and 2008 ambient temperatures were $(F=1.3 ; \mathrm{df}=3,6 ; P=0.36),(F=0.84 ; \mathrm{df}=3,6 ; P=0.52),(F=11.2 ; \mathrm{df}=3,6 ; P<0.01),(F=14.42 ; \mathrm{df}=3,6 ; P<0.01)$, and $(F=15.24 ;$ $\mathrm{df}=2,4 ; P<0.02)$, respectively. 
Table 3. Time (mean $\pm \mathrm{SE}$ ) to attain $50^{\circ} \mathrm{C}$ under ambient conditions and in containers with $T$. castaneum, $R$. dominica, and psocids in concrete silos

\begin{tabular}{|c|c|c|c|c|c|}
\hline \multirow{2}{*}{ Depth $(\mathrm{m})$} & \multirow{2}{*}{$\frac{2007}{\text { Ambient }}$} & \multicolumn{4}{|c|}{2008} \\
\hline & & Ambient & T. castaneum containers & R. Dominica containers & Psocid containers \\
\hline 0 (top) & $4.7 \pm 0.4 \mathrm{a}$ & $3.3 \pm 0.8 \mathrm{a}$ & $6.3 \pm 0.6 \mathrm{a}$ & $6.3 \pm 0.6 \mathrm{a}$ & \\
\hline 10 & $3.7 \pm 0.3 \mathrm{ab}$ & $2.2 \pm 1.16 \mathrm{a}$ & $4.3 \pm 1.0 \mathrm{ab}$ & $4.1 \pm 1.1 \mathrm{ab}$ & \\
\hline 20 & $2.8 \pm 0.1 b$ & $1.8 \pm 1.0 \mathrm{a}$ & $2.8 \pm 1.1 \mathrm{~b}$ & $2.8 \pm 1.1 \mathrm{~b}$ & $3.6 \pm 1.2 \mathrm{a}$ \\
\hline 30 (bottom) & $2.4 \pm 0.6 \mathrm{~b}$ & $1.8 \pm 1.0 \mathrm{a}$ & $2.8 \pm 1.1 \mathrm{~b}$ & $2.8 \pm 1.1 \mathrm{~b}$ & $3.6 \pm 1.2 \mathrm{a}$ \\
\hline
\end{tabular}

Means within a column followed by different letters are significantly different. ANOVA results for ambient (2007) and ambient (2008), and T. castaneum, $R$. dominica, and psocid containers were $(F=5.8 ; \mathrm{df}=3,8 ; P=0.02),(F=0.6 ; \mathrm{df}=3,8 ; P=0.64),(F=2.9 ; \mathrm{df}=3,8 ; P=$ $0.10),(F=2.8 ; \mathrm{df}=3,8 ; P=0.11)$, and $(F=0.0 ; \mathrm{df}=1,4 ; P=1.0)$, respectively.

decreased to $49.9^{\circ} \mathrm{C}$ at the bottom (Table 2), and had a range of $12.3-63.5^{\circ} \mathrm{C}$. The target temperature of $50^{\circ} \mathrm{C}$ was more rapidly attained with increasing depth in the heated silos (Table 3 ). In the T. castaneum containers and in the $R$. dominica containers, the target ambient temperature of $50^{\circ} \mathrm{C}$ was more rapidly attained with increasing depth from the top to bottom (Table 3). In the psocid containers, a temperature of $50^{\circ} \mathrm{C}$ was not attained at the top and no data were collected at a depth of $10 \mathrm{~m}$ because the HOBO malfunctioned. At $20 \mathrm{~m}$ and at the bottom, the target of $50^{\circ} \mathrm{C}$ was attained after $3.6 \mathrm{~h}$ (Table 3).

Beetles, 2007. $R$. dominica. The pattern of adult beetle mortality at the four silo depths was similar in the control and heated silos $(F=2.9 ; \mathrm{df}=3,12 ; P=$ 0.08; Fig. 1A). Depth had no significant effect on mortality $(F=2.8 ; \mathrm{df}=3,12 ; P=0.08)$. As expected, heat treatment affected mortality $(F=74.3 ; \mathrm{df}=1,2$; $P<0.01$; Fig. 1A); mean mortalities in the control and heated silos were $6.1 \pm 1.0$ and $72.4 \pm 9.7 \%$, respectively. Progeny production of $R$. dominica at the four silo depths was different in controls and treatments $(F=5.5 ; \mathrm{df}=3,12 ; P<0.02 ;$ Fig. 1B $)$. This significant interaction between heat treatment and depth in relation to progeny production is a result of a similar number of progeny (485-511) produced in the arenas from the four depths in the control silos and variable progeny production in the arenas from the four depths in the heated silos (Fig. 1B).

T. castaneum. The pattern of adult beetle mortality at the four silo depths was similar in the control and heated silos $(F=1.1 ; \mathrm{df}=3,12 ; P=0.40$; Fig. $1 \mathrm{C})$. Depth had no significant effect on mortality $(F=0.9$; $\mathrm{df}=3,12 ; P=0.49)$. As with $R$. dominica, heat treatment affected mortality $(F=205.7 ; \mathrm{df}=1,2 ; P<0.01$; Fig. 1C); mean mortalities in the control and heated silos were $1.1 \pm 0.4$ and $93.2 \pm 6.8 \%$, respectively. The pattern of T. castaneum progeny produced at the four silo depths was similar in the control and heated silos $(F=0.8 ; \mathrm{df}=3,12 ; P=0.52 ;$ Fig. 1D). Depth had no significant effect on number of progeny $(F=0.5 ; \mathrm{df}=$ $3,12 ; P=0.71)$, whereas heat treatment affected progeny production $(F=128.1 ; \mathrm{df}=1,2 ; P<0.01$; Fig. 1C); mean numbers of progeny in the control and heated silos were $465.9 \pm 23.1$ and $31.0 \pm 27.6$, respectively.

Beetles, 2008. $R$. dominica. The pattern of adult beetle mortality at the four silo depths was different in the control and heated silos $(F=7.9 ; \mathrm{df}=3,12 ; P<$ 0.01; Fig. 2A). This significant interaction between
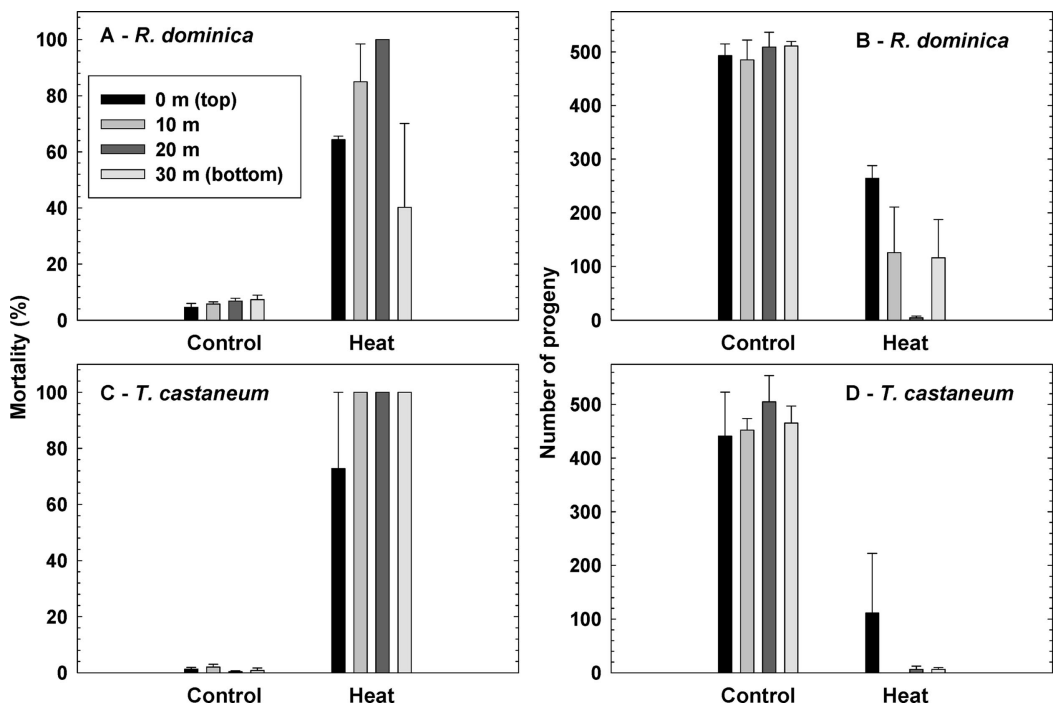

Fig. 1. Effects of heat treatment on R. dominica adult mortality (A) and progeny production (B) and on T. castaneum adult mortality (C) and progeny production (D) in 2007. 

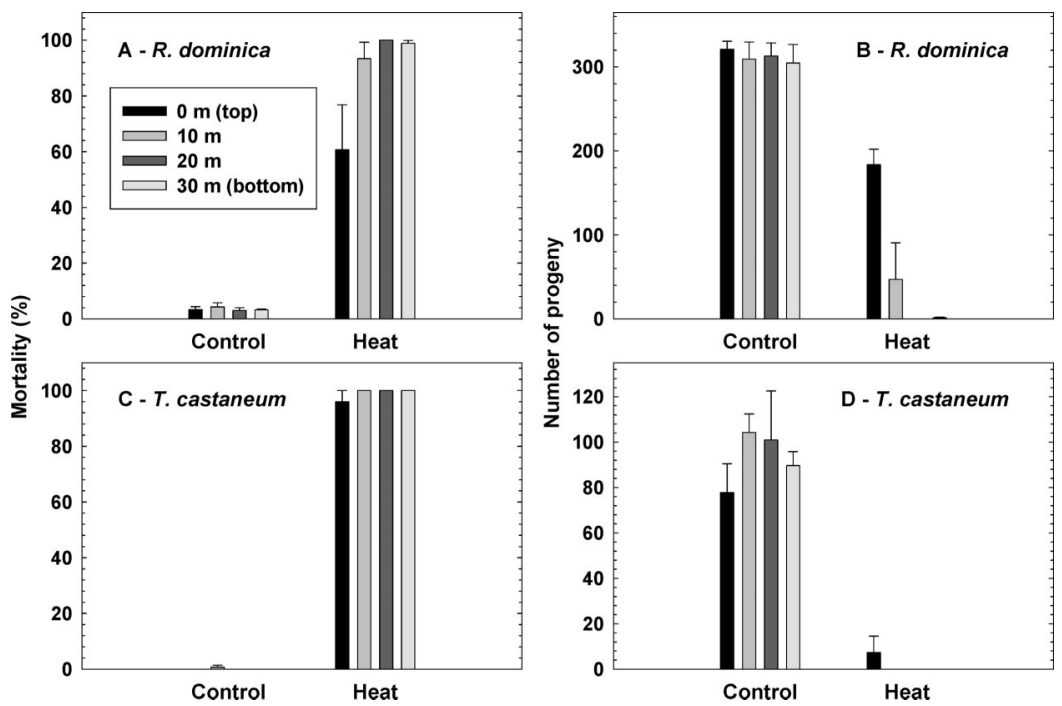

Fig. 2. Effects of heat treatment on R. dominica adult mortality (A) and progeny production (B) and on T. castaneum adult mortality (C) and progeny production (D) in 2008.

treatment and depth in relation to adult beetle mortality is a result of similar mortality of 3-4\% occurring at the four depths in the control silos and mortality increasing from $61 \%$ at the top of the heated silos to $100 \%$ at depths of $20 \mathrm{~m}$ and at the bottom (Fig. 2A). The pattern of number of $R$. dominica progeny produced at the four silo depths was different in the control and heated silos $(F=11.0 ; \mathrm{df}=3,12 ; P<0.01$; Fig. 2B). As in 2007, progeny production in untreated controls at the four depths was similar (304-321), whereas progeny production in the heated silos decreased from an average of 184 at the top of the heated silos to few or none at the bottom (Fig. 2B).

T. castaneum. The pattern of adult beetle mortality at the four silo depths was similar in the control and heated silos $(F=0.8$; $\mathrm{df}=3,12 ; P=0.53$; Fig. $2 \mathrm{C})$. Depth had no significant effect on mortality $(F=1.2$; df $=3,12 ; P=0.34)$, but heat treatment $\operatorname{did}(F=$ 2318.5; df $=1,2 ; P<0.01$; Fig. 2C). Mean mortalities in the control and heated silos were $0.2 \pm 0.18 \%$ and $99.0 \pm 1.0 \%$, respectively. The pattern of $T$. castaneum progeny production in the arenas from the four silo depths was similar in the control and heated silos $(F=$ 1.6; $\mathrm{df}=3,12 ; P=0.25$; Fig. 2D). Depth had no significant effect on progeny production $(F=0.1 ; \mathrm{df}=$ $3,12 ; P=0.95)$, but heat treatment $\operatorname{did}(F=507.2 ; \mathrm{df}=$ 1,$2 ; P<0.01$; Fig. 2D). Mean numbers of progeny in the control and heated silos were $93.2 \pm 6.6$ and $1.8 \pm$ 0.38 , respectively.

Psocids. The pattern of L. corrodens mortality at the four silo depths was similar in the control and heated silos $(F=1.0 ; \mathrm{df}=3,12 ; P=0.44$; Table 4$)$. Depth had no significant effect on mortality $(F=1.0$; df $=3,12$; $P=0.44)$, but heat treatment $\operatorname{did}(F=287.7 ; \mathrm{df}=1$, 2; $P<0.01$; Table 4). Mean mortalities in the control and heated silos were $38.3 \pm 9.0$ and $100.0 \%$, respectively. Similar results were found for L. decolor where the pattern of mortality at the four silo depths was similar in the control and heated silos $(F=1.9$; $\mathrm{df}=$ 3, 12; $P=0.19$; Table 4$)$. Depth had no significant effect on mortality $(F=1.9$; df $=3,12 ; P=0.18)$ but heat treatment $\operatorname{did}(F=150.5 ; \mathrm{df}=1,2 ; P<0.01$; Table 4). Mean mortalities in the control and heated silos were $15.8 \pm 4.8$ and $92.5 \pm 5.4 \%$, respectively.

\section{Discussion}

Based on the results of this study, the Mobile Heat Treatment Unit with a heat output potential of 440 $\mathrm{kW}$, can produce enough heat in concrete silos to maintain temperatures of $50^{\circ} \mathrm{C}$ for $6 \mathrm{~h}$-the target conditions of the heat treatment. With the exception of the bottom of the silos, slightly higher temperatures were attained during heat treatment in 2008 compared

Table 4. Effect of heat treatment on mortality of $L$. corrodens and $L$. decolor

\begin{tabular}{lccc}
\hline \hline Species & Treament & Depth $(\mathrm{m})$ & $\begin{array}{c}\text { Mortality } \\
(\%)\end{array}$ \\
\hline L. corrodens & Control & 0 (top) & $31.7 \pm 16.4 \mathrm{a}$ \\
& & 10 & $46.7 \pm 26.0 \mathrm{a}$ \\
& 20 & $43.3 \pm 15.9 \mathrm{a}$ \\
& Heat & 0 & $31.7 \pm 22.4 \mathrm{a}$ \\
& & 10 & $100.0 \pm 0.0 \mathrm{~b}$ \\
& & 20 & $100.0 \pm 0.0 \mathrm{~b}$ \\
& & 0 & $100.0 \pm 0.0 \mathrm{~b}$ \\
& & 10 & $18.3 \pm 15.9 \mathrm{a}$ \\
& & 20 & $13.3 \pm 1.7 \mathrm{a}$ \\
& & 30 & $11.7 \pm 9.3 \mathrm{a}$ \\
& & 0 & $70.0 \pm 11.5 \mathrm{a}$ \\
& & 10 & $100.0 \pm 0.0 \mathrm{a}$ \\
& & 20 & $100.0 \pm 0.0 \mathrm{a}$ \\
& & 30 & $100.0 \pm 0.0 \mathrm{a}$ \\
\hline
\end{tabular}

For each species, means within a column followed by different letters are significantly different. 
with 2007 despite the silos being a little cooler in 2008 . Because of the heat introduction at the bottom of silos, the venting of the heating gas at the top of the heated silos, and air draft outside the silos, temperatures in heated silos increased with depth, i.e., target ambient temperatures of $50^{\circ} \mathrm{C}$ were not achieved at the top of the silos. Ways of mitigating this heat loss need to be found for heat treatments in concrete silos to achieve the desired target conditions.

We found that when temperature was $\approx 50^{\circ} \mathrm{C}$ for $6 \mathrm{~h}$, parental mortality of $R$. dominica and T. castaneum, and both psocid species was $98-100 \%$. The production of beetle progeny in cases where parental mortality was as high as $98-100 \%$ is explained by the fact that $85 \mathrm{~g}$ of infested wheat and $2.5 \mathrm{~g}$ of dust from the $R$. dominica culture and $1.5 \mathrm{~g}$ of flour from the T. castaneum culture comprised the media used in containers for these two species. It is very likely the aforementioned infested wheat, dust, and flour had immature stages of these two species that may have survived the heat treatment and were counted two and $4 \mathrm{wk}$ after treatment. In addition, adults could easily have laid eggs before they died. This is because containers were placed in the silos the afternoon before testing began (testing began the next morning), which means adult insects had several hours to lay eggs before they got killed or were removed during counting.

In general, parental mortality of R. dominica was less than parental mortality of T. castaneum, resulting in greater progeny production of $R$. dominica compared with T. castaneum. Previous studies have indicated that R. dominica has higher progeny production at 32 than at $27^{\circ} \mathrm{C}$, and may mean that it is less impacted by elevated temperatures compared with $T$. castaneum (Vardeman et al. 2006, Chanbang et al. 2007). Actual heat tolerance of these species could be determined by examining their lag periods (time in minutes where their survival is $100 \%$ ) (Boina et al. 2008) or by estimating lethal times (LTs), for example, $\mathrm{LT}_{50}$ and $\mathrm{LT}_{99}$ (Finney 1971). In addition, the grain kernels apparently offered some protection for immature $R$. dominica. Even though the target temperature of $50^{\circ} \mathrm{C}$ was attained at most of the silo depths some progeny production occurred, which shows the insulating properties of the wheat in which insects were placed. We found that the 86.5, 99, and $300 \mathrm{~g}$ of wheat, in which insects were placed, provided good insulation from heat. Temperature reduction in insect containers was proportional to the amount of wheat placed in them, i.e., greater insulation in the psocid containers compared with the beetle containers. This result emphasizes the importance of sanitation and cleaning before heat treatment to remove organic material that could help insulate insects from heat. $R$. dominica is the most serious insect pest of stored small grains (Phillips and Throne 2010) and our finding that it tolerates recommended heat treatment conditions should be considered when applying heat to empty grain silos for pest control.

In a study that investigated the use of heat to disinfest 50-MT metal silos, Beckett and Qaisrani (2003) found that a temperature of $54^{\circ} \mathrm{C}$ was sufficient to kill all $T$. castaneum adults and that grain temperatures of 53.4 and $55.2^{\circ} \mathrm{C}$ for periods of 4 and $3 \mathrm{~h}$, respectively, caused $99.99 \%$ mortality of the earliest immature stages of $R$. dominica. Based on this information, a temperature of $54^{\circ} \mathrm{C}$ for $6 \mathrm{~h}$ would have, perhaps, provided complete mortality of all stages of T. castaneum and $R$. dominica and adult $L$. decolor and $L$. corrodens during the current study. Beckett and Qaisrani (2003) also suggest that heat disinfestation is effective and economical when high inlet temperatures are used to produce rapid heating to a temperature where complete insect mortality is guaranteed.

Heat treatment is effective against $L$. decolor and $L$. corrodens. We found $L$. decolor to be less impacted by heat than L. corrodens. This is because there was $100 \%$ mortality of $L$. corrodens in all depths in the heated bins whereas $30 \%$ survival of $L$. decolor occurred at the top of the silos where ambient and psocid container temperatures did not reach $50^{\circ} \mathrm{C}$ but were 46.9 and $40.6^{\circ} \mathrm{C}$, respectively. Our results for $L$. decolor are consistent with those of Beckett and Morton (2003). Their research indicates eggs are the most heat-tolerant Lipsocelis stage and eggs of L. decolor were more heat tolerant than those of $L$. bostrychophila and $L$. paet $a$ at temperatures from 46 to $51^{\circ} \mathrm{C}$. However, they found that below $46^{\circ} \mathrm{C}$, L. paeta became considerably more tolerant than the other two species. Based on our results and those of Beckett and Morton (2003), L. corrodens seems to have a lower heat tolerance than $L$. decolor, L. paeta, and L. bostrychophila. The tolerance of the last three preceding species may point to their adaptation to warmer conditions; in fact, the relative hardiness of $L$. decolor may be a key reason why the species thrives in the considerable temperature range of the southern Australian climate (Beckett and Morton 2003).

A possible means through which Liposcelis species such as L. decolor may tolerate heat is via the expression of small heat-inducible proteins (Guedes et al. 2008). In their study, Guedes et al. (2008) found higher variability and tolerance to heat shock stress in the stored-product psocid L. entomophila than in Lepinotus reticulatus Enderlein (Psocoptera: Trogiidae). Heat shock protein of $70 \mathrm{kDa}$ (HSP 70) was not detected in either of the psocid species, but they found that L. entomophila expresses small heat-inducible proteins (23 and mainly $27 \mathrm{kDa}$ ) sharing a common epitope with HSP 70, which were not detected in $L$. reticulatus and seem to underlay the higher heat shock tolerance of $L$. entomophila. They concluded that the lack of heat-inducible proteins in L. reticulatus may be responsible for the adverse effects of high temperatures on this species. L. decolor, L. entomophila, $L$. paeta, and $L$. rufa have been shown to have higher optimal temperatures for development and will probably occur commonly in warmer environments (Gautam et al. 2010 and references therein). According to them, this observation may also explain why these species are commonly found in large numbers during warmer periods of the year when temperatures in grain storages are extremely high. 
The mortalities of $L$. corrodens and $L$. decolor in the control silos were 38.3 and $15.8 \%$, respectively. The higher mortality of $L$. corrodens compared with that of L. decolor may indicate that the latter is more tolerant to low relative humidity conditions that may have existed during the experiment than the former. According to Devine (1982), psocids maintain body water levels by absorbing atmospheric water vapor when relative humidity is $\geq 60 \%$; however, below this level, more water is lost than gained resulting in dehydration and death. Therefore, we suggest that it is likely that L. decolor may be better adapted at absorbing atmospheric water vapor at low relative humidities than $L$. corrodens.

As mentioned, psocid eggs are the most heat-tolerant stage (Beckett and Morton 2003). Therefore, it is quite likely that the treatments conducted would be less effective against mixed-age populations of psocids. This means temperatures of $50^{\circ} \mathrm{C}$ would have to be achieved and maintained for longer, and greater pretreatment hygiene would be required for heat treatment to be effective.

In conclusion, heat treatment for empty elevator bins would help in the adoption of integrated pest management (IPM) strategies for stored-product insects (Hagstrum and Flinn 1996, Hagstrum and Subramanyam 2000). Reducing reliance on phosphine for empty silo fumigation also would be compatible with the IPM approach. In the disinfestations of empty grain storages, IPM programs could comprise sanitation and cleaning along with heat treatments, however, because the presence of residual grain could compromise efficacy, additional research to evaluate the insulating properties of small amounts of grain would be necessary. Perhaps a longer time period for heating or higher temperatures would be necessary to complete disinfestations, and a thorough sanitation and cleaning of the silo before heat treatment would undoubtedly increase efficacy.

\section{Acknowledgments}

We thank Randy Beeby for technical support. In addition, we extend our appreciation to E. Mockford who confirmed the identities of L. decolor and L. corrodens. We also thank United Cooperative, Inc., in Marshall, OK, for providing access to elevator facilities and Temp-Air, Inc., for the use of the portable propane heating units. We thank Michael Reiskind and Richard Grantham for reviewing an earlier draft of this manuscript. This work was funded by the Oklahoma Agricultural Experiment Station (project no. OKL02695).

\section{References Cited}

Arthur, F. H., D. W. Hagstrum, P. W. Flinn, C. Reed, and T. Phillips. 2006. Insect populations in grain residues associated with commercial Kansas grain elevators. J. Stored Prod. Res. 42: 226-239.

Bailey, J. E. 1992. Whole grain storage, pp. 157-182. In D. B. Sauer (ed.), Storage of cereal grains and their products. American Association of Cereal Chemists, Inc., St. Paul, MN.
Beckett, S. J., and R. Morton. 2003. The mortality of three species of Psocoptera, Liposcelis bostrychophila Badonnel, Liposcelis decolor Pearman, and Liposcelis paeta Pearman, at moderately elevated temperatures. J. Stored Prod. Res. 39: 103-115.

Beckett, S. J., and R. Qaisrani. 2003. Heat disinfestation of farm silos before inloading, pp. 803-806. In P. F. Credland, D. M. Armitage, C. H. Bell, P. M. Cogan, and E. Highley (eds.), Proceedings of the 8th International Working Conference on Stored-Product Protection, 22-26 July 2002, York, United Kingdom. CAB International, Wallingford, Oxon, United Kingdom.

Boina, D. R., Bh. Subramanyam, and S. Alavi. 2008. Dynamic model for predicting survival of mature larvae of Tribolium confusum during facility heat treatments. J. Econ. Entomol. 101: 989-997.

Chanbang, Y., F. H. Arthur, G. E. Wilde, and J. E. Throne. 2007. Efficacy of diatomaceous earth to control Rhyzopertha dominica (F.) (Coleoptera: Bostrichidae) in rough rice: impacts of temperature and relative humidity. Crop Prot. 26: 923-929.

Chaudhry, M. Q. 2000. Phosphine resistance: a growing threat to an ideal fumigant. Pestic. Outlook, June 2000: $88-91$.

Dean, D. A. 1911. Heat as a means of controlling mill insects. J. Econ. Entomol. 4: 142-161.

Dean, D. A. 1913. Further data on heat as a means of controlling mill insects. J. Econ. Entomol. 6: 40-53.

Devine, T. L. 1982. The dynamics of body water in the booklouse Liposcelis bostrychophilus (Badonnel). J. Exp. Zool. 222: 335-347.

Finney, D. J. 1971. Probit analysis. Cambridge University Press, London, United Kingdom.

Gautam, S. G., G. P. Opit, and K. L. Giles. 2010. Population growth and development of the psocid Liposcelis rufa (Psocoptera: Liposcelididae) at constant temperatures and relative humidities. J. Econ. Entomol. 103: 1920-1928.

Guedes, R.N.C., K. Y. Zhu, G. P. Opit, and J. E. Throne. 2008. Differential heat shock tolerance and expression of heatinducible proteins in two stored-product psocids. J. Econ. Entomol. 101: 1974-1982.

Hagstrum, D. W. 1989. Infestation by Cryptolestes ferrugineus (Coleoptera: Cucujidae) in newly harvested wheat stored on three Kansas farms. J. Econ. Entomol. 82: 655659 .

Hagstrum, D. W., and P. W. Flinn. 1996. Integrated pest management, pp. 399 - 408. In B. Subramanyam and D. W Hagstrum (eds.), Integrated management of insects in stored products. Marcel Dekker, New York.

Hagstrum, D. W., and B. Subramanyam. 2000. Monitoring and decision tools, pp. 1-28. In B. Subramanyam and D. W. Hagstrum (eds.), Alternatives to pesticides in stored-product IPM. Marcel Kluwer Academic Publishers. Norwell, MA.

Kučerová, Z. 2002. Weight losses of wheat grains caused by psocid infestation (Liposcelis bostrychophila: Liposcelididae: Psocoptera). Plant Prot. Sci. 38: 103-107.

Mahroof, R., B. Subramanyam, and D. Eustace. 2003a. Temperature and relative humidity profiles during heat treatment of mills and its efficacy against Tribolium castaneum (Herbst) life stages. J. Stored Products Res. 39: 555-569.

Mahroof, R., B. Subramanyam, J. E. Throne, and A. Menon. 2003b. Time-mortality relationships for Tribolium castaneum (Coleoptera: Tenebrionidae) life stages exposed to elevated temperatures. J. Econ. Entomol. 96: 1345-1351.

Mills, K. A. 1983. Resistance to the fumigant hydrogen phosphide in some stored product insect species associated 
with repeated inadequate treatments. Mitt. Dtsch. Ges. Allg. Angew. Entomol. 4: 98-101.

Nayak, M. K. 2006. Psocid and mite pests of stored commodities: small but formidable enemies, pp. 1061-1073. In I. Lorini, B. Bacaltchuk, H. Beckel, D. Deckers, E. Sundfeld, J. P. dos Santos, J. D. Biagi, J. C. Celaro, L. R. D’A. Faroni, L de O. F. Bortolini, et al. (eds.), Proceedings of the 9th International Working Conference on Stored Product Protection, 15-18 October 2006. Brazilian Postharvest Association-ABRAPOS, Campinas, Brazil.

Nayak, M. K., and P. J. Collins. 2008. Influence of concentration, temperature, and humidity on the toxicity of phosphine to the strongly phosphine resistant psocid $\mathrm{Li}$ poscelis bostrychophila Badonnel (Psocoptera: Liposcelididae). Pest Manag. Sci. 64: 971-976.

Nayak, M. K., P. J. Collins, and S. R. Reid. 1998. Efficacy of grain protectants and phosphine against Liposcelis bostrychophila, L. entomophila, and L. paeta (Psocoptera: Liposcelidae). J. Econ. Entomol. 91: 1208-1212.

Nayak, M. K., P. J. Collins, and H. Pavic. 2002a. Long-term effectiveness of grain protectants and structural treatments against Liposcelis decolor (Pearman) (Psocoptera: Liposcelididae), a pest of stored products. Pest Manag. Sci. 58: 1223-1228.

Nayak, M. K., P. J. Collins, and H. Pavic. 2002b. Resistance to phosphine in psocids: Challenges ahead!, pp. 113-118. In E. J. Wright, H. J. Banks, and E. Highley (eds.), Proceedings of the 2nd Australian Postharvest Technical Conference, 1-4 August 2000, Adelaide, Australia.

Nayak, M. K., P. J. Collins, H. Pavic, and R. A. Kopittke. 2003. Inhibition of egg development by phosphine in the cosmopolitan pest of stored products Liposcelis bostrychophila (Psocoptera: Liposcelididae). Pest Manag. Sci. 59: 1191-1196.

Opit, G. P., and J. E. Throne. 2008. Population growth and development of the psocid Lepinotus reticulates at constant temperatures and relative humidities. J. Econ. Entomol. 101: 605-615.

Phillips, T. W., and J. E. Throne. 2010. Biorational approaches to managing stored-product insects. Annu. Rev. Entomol. 55: 375-397.

Reed, C. R., D. W. Hagstrum, P. W. Flinn, and R. F. 2003. Wheat in bins and discharge spouts, and grain residues on floors of empty bins in concrete grain elevators as habitats for stored-grain beetles and their natural enemies. J. Econ. Entomol. 96: 996-1004.

Rees, D. 2003. Psocoptera (psocids) as pests of bulk grain storage in Australia: a cautionary tale to industry and researchers, pp. 59-64. In P. F. Credland, D. M. Armitage, C. H. Bell, P. M. Cogan, and E. Highley (eds.), Advances in Stored Product Protection, Proceedings of the 8th International Working Conference on Stored Product Protection, 22-26 July 2002, York, United Kingdom. CAB International, Wallingford, United Kingdom.

Rees, D. 2004. Insects of stored products. CSIRO Publishing, Collingwood, VIC, Australia.

Roesli, R., B. Subramanyam, F. J. Fairchild, and K. C. Behnke. 2003. Trap catches of stored-product insects before and after heat treatment in a pilot feed mill. J. Stored Products Res. 39: 521-540.

Sayaboc, P. D., A.J.G. Gibe, and F. M. Caliboso. 1998. Resistance of Rhyzopertha dominica (F.) (Coleoptera: Bostrychidae) to phosphine in the Philippines. Philipp. Entomol. 12: 91-95.

Steel, R.G.D., and J. H. Torrie. 1960. Principles and procedures of statistics. McGraw-Hill, New York.

Taylor, R.W.D. 1989. Phosphine-a major fumigant at risk. Int. Pest Control 31: 10-14.

Taylor, R.W.D., and D. Halliday. 1986. The geographical spread of resistance to phosphine by coleopterous pests of stored products, pp. 607-613. In Proceedings of the British Crop Protection Conference, Pests and Diseases, 17-20 November 1986, Brighton, United Kingdom. British Crop Protection Council, Surrey, United Kingdom.

Tilley, D. R., M. E. Casada, and F. H. Arthur. 2007. Heat treatment for disinfestations of empty grain storage bins. J. of Stored Products Res. 43: 221-228.

Vardeman, E. A., F. H. Arthur, J. R. Nechols, and J. F. Campbell. 2006. Effect of temperature, exposure interval and depth of diatomaceous earth on distribution, mortality, and reproduction of the lesser grain borer, Rhyzopertha dominica (F.) (Coleoptera: Bostrichidae) in stored wheat. J. Econ. Entomol. 99: 1017-1024.

Zettler, J. L. 1997. Influence of resistance of future fumigation technology, pp. 445-454. In E. J. Donahaye, S. Navarro, and A. Varnava (eds.), Proceedings of the International Conference on Controlled Atmospheres and Fumigation in Stored Products, 21-26 April 1996. Printco Ltd., Nicosia, Cyprus.

Zettler, J. L., and G. W. Cuperus. 1990. Pesticide resistance in Tribolium castaneum (Coleoptera: Tenebrionidae) and Rhyzopertha dominica (Coleoptera: Bostrichidae) in wheat. J. Econ. Entomol. 83: 1677-1681.

Received 1 April 2011; accepted 5 April 2011. 